\title{
ANALYSIS OF THE STATE OF TOURISM OF THE WESTERN REGION OF UKRAINE
}

\author{
Maryniak Ya. O., Stetsko N. P.
}

\section{INTRODUCTION}

At the present stage of economic development in many countries, tourism is one of the leading industries. Ukraine is one of the countries where revenues from tourism are less than one percent. However, in recent years, many attempts have been made to expand the functioning of the tourism industry. This is done by addressing these shortcomings and creating an appropriate legislation.

The basis of the law concerning tourism in Ukraine is the Constitution of Ukraine, Laws adopted by the Verkhovna Rada of Ukraine, Resolutions of the Cabinet of Ministers, programs adopted by regional councils. The adoption of the Law "On Tourism" laid the legal foundations for the functioning of the tourism sector, an integral part of which are tourism enterprises.

The functioning of tourism enterprises in Ukraine depends on the main sectors of the economy and is in some way a reflection of them. Tourism as an industry has both positive and negative consequences for a specific territory.

The Western region through the prism of a set of factors is one of the most important in the economy of Ukraine. The main objectives of this study are:

- to study the essence of tourist enterprises and their role in the economy of the country, the Western region;

- to analyze the state of tourist-recreational and resort infrastructure;

- to find out the possibilities of choosing the correct (effective) legal form of a tourist enterprise;

- to investigate the peculiarities of the application of certain research methods at specific stages of the study;

- to study the shaping factors of the functioning of the Western region as a landfill for economic purposes, including recreational;

- to diagnose the actions of tourism entities; 
- to consider ways of further development of the territory of the Western frontier through the prism of the tourist concept;

The object of research is the activity and analysis of the functioning of tourism entities.

The subject of the study are the main statistical indicators that reveal the main features of the tourism business in the Western region.

Methodological bases and research methods. The theoretical foundations of this study are the works of foreign and domestic scientists in various fields of tourism. Various aspects of tourism are covered in the works of geographers, economists, philosophers, educators and specialists in other fields of knowledge. The greatest achievements in this area are reflected in monographs V.F. Kifyak (2003), M.R. Gnatyuk (2006), N.S. Kudla (2006), Andrzej Kowalczyk (2001), O.O. Lyubitseva (2002), Y. Marynyak (2008), (2014), I.M. Schcola (2003), G.M. Zakharchin (2008).

It is worth mentioning the achievements of leading domestic and foreign scientists, in particular, V. Yevdokymenko (1996), M.I. Dolishnyi (1997), O.I. Shabliy (1994).

The study is based on published statistical publications and used various scientific methods.

Tourist activity - activity related to the organization of all forms of departure of people from places of permanent residence for health purposes, satisfaction of cognitive interests or for professional - business purposes with at least one night stay paid by a company for temporary stay.

According to the functional characteristics the enterprises engaged in tourist activities are divided into tour operators and travel agents. These terms determine the direction of entrepreneurial activity of a travel agency or company. In the literature and legislation of many countries, there are different interpretations of the terms "tour operator" and "travel agent".

A tour operator in Ukraine must obtain a license for tour operator activities.

The licensing body of tour operators is currently the State Agency for Tourism Development, which takes care of tourism, which in September 2019 became part of the Ministry of Culture and Information Policy of Ukraine. Previously, the Ministry of Economic Development, Trade and Agriculture dealt with this activities.

\section{Tourist-recreational and resort infrastructure}

Tourism is a cross-sectoral activity, the level of which depends on the state of other sectors of the economy, so the feature of statistical 
information in tourism is the variety of sources of information for its receipt.

The actual data for this study are taken from:

- statistical reporting of national and regional monitoring of economic sectors: hotels and restaurants, transport and communications, rental and provision of services, health care and social services, provision of other utilities, social and personal services;

- reporting of the Ministry of Economic Development, Trade and Agriculture, the Ministry of Infrastructure, the Ministry of Culture and Information Policy, the Ministry of Youth and Sports, the State Border Guard Service of Ukraine, the State Agency of Ukraine for Tourism and Resorts (State Agency for Tourism Development);

- sample surveys conducted by the State Statistics Service of Ukraine.

The Western region of Ukraine as a holistic object of social geography has its own problems. In the schemes of social and economic regioning, the Western region acts as a holistic organism in the schemes. The difference is that ${ }^{1}$ includes Lviv, Ivano-Frankivsk, Transcarpathian, Chernivtsi, Ternopil, Khmelnytskyi, Rivne, Volyn regions, and does not include Khmelnytskyi region ${ }^{2}$.

The Western region takes the second place according to the area $\left(131,3\right.$ thousand $\left.\mathrm{km}^{2}\right)$ and the population of 11,3 million people. It unites the largest number of regions (8) and the core is the city of Lviv. There is the largest number of towns and cities of the urban type within this area. Almost all regions (except for Ternopil and Khmelnytskyi) are transboundary territories that unites them in the future development, and determines their specialization on the basis of interaction with these states.

The boundaries of this area have been formed due to the activities of the primary sector of the economy and the products mainly produced by means of production and products for military purposes. The next component of the primary sector of the economy is agriculture, which undergoes a serious reorientation.

The territory is a region with excessive number of workplaces. A major challenge is the improvement of the environment.

${ }^{1}$ Долішній М.І., Шевчук Л.Т. Соціально-економічне районування України. Львів. 1997. 50 с.

2 Соціально-економічна географія України : навч.посібник / за ред. О.І. Шаблія. Львів : Світ, 1994. 608 с. 
The strategy of regional development requires a serious adjustment of the tertiary sector of the economy, especially, the services sphere (tourism). To do this, it is necessary to determine the place of tourism in the development strategy; the key point of this strategy is the activity of tourism enterprises. Due to the fact that tourism is one of the most popular types of recreation all over the world, it is necessary to study in detail the peculiarities of development of this sphere and its interrelation with social problems in the regions of Western Ukraine which are close to the countries of the European Union.

At the same time, a more detailed study is required for the tourism sphere of the border areas of Western Ukraine, which are sufficiently attractive for the development of this type of activity, taking into consideration the strengthening of European integration processes and the prospects for expanding cooperation with the countries of the European Union.

The infrastructure includes resort areas, hotels, sanatoriums, recreation centers, and health camps for young people, campsites, motels and more.

Infrastructural recreational and tourist potential, which complements its real potential, is a network of recreational facilities and hotels, which are quite significant and are at the level of $10,8 \%$ and $22,4 \%$, respectively, as a percentage of the national ${ }^{3}$.

The share of the number of beds (places) in sanatoriums and health facilities of the Western region increased from $6,8 \%$ in 2000 to $121,7 \%$ in 2015. This indicates the modernization of the bed stock of sanatoriums and increase in their efficiency activities.

In total, the Western region is represented by 324 long-stay establishments with a total number of beds (places) per month with a maximum deployment of 546544 units. Respectively, there were 109 institutions in the Lviv oblast (18,263 beds), in the Volyn oblast $65(3,835)$, in the Transcarpathian oblast $-62(6,614)$, in the IvanoFrankivsk region - $36(3,798)$, in the Rivne region $-22(2,802)$, in the Ternopil oblast - 18 (2230) and in Chernivtsi - 14 (1492).

In the typical structure of sanatoriums and health facilities of the Western region, the most numerous are sanatoriums. They make up $33.0 \%$ of the number and more than $53.9 \%$ of the bed stock of medical and health facilities. On their basis in 2010300 thousand persons were made healthy, that made $75,4 \%$ of all recovered in establishments of

${ }^{3}$ Регіони України. 2018: стат. зб. Ч. 1. / За ред. І.С. Вернера. Київ, 2019. 323 с. 
medical and improving type, and only 10,0 thousand persons had a rest and have recovered in boarding houses with treatment $(25,1 \%)$, 23.7 thousand people $(6,0 \%)$ - in sanatoriums and 3,6 thousand people $(0,9 \%)$ - in spas.

Positive changes have taken place in improving their quality characteristics. This happened, firstly, due to the re-profiling of a number of boarding houses with treatment in sanatoriums; secondly, due to the construction of new small-capacity facilities with increased comfort and the reconstruction of sanatoriums with the conversion of rooms into "suites" and "junior suites". The result was a significant influx of healed people in the Western region.

In the Carpathian recreational region, there are 60 sanatoriums, 17 boarding houses with treatment, which have about 25 thousand beds. There are three resort clinics in the region. In 10 rest homes for 2,500 people, up to 50,000 people recover every year. Sanatoriums (70 of them in the region), recreation centers (120), labor and recreation camps for high school students (1150) and country children's camps (over 180) are of great importance for the recovery of the predominantly urban population. Transcarpathia accounts for two thirds of tourist facilities and almost half of the places (45\%). In second place in terms of both the number of institutions $-23 \%$ and the number of places $-31 \%$ is Lviv region. Approximately the same number of facilities are located in Chernivtsi and Ivano-Frankivsk oblasts. Almost two thirds of all places belong to camps and tourist complexes, a third are tourist hotels. For fans of mountain skiing there are more than 50 lifts and cable cars. Almost half of them are in the Transcarpathian tourist complexes, the other in equal quantities in the tourist establishments of Lviv and IvanoFrankivsk ${ }^{4}$.

In the Ternopil oblast there are 18 long-stay health facilities, sanatoriums -9 , the number of places -1735 , sanatoriums, 5 units, the number of places -417 , recreation centers -2 , the number of places in them -175 .

In the Volyn region there are 21 sanatoriums with a total capacity of 4289 and in Rivne 13 and 3821, respectively.

The territory of the Carpathian region is crossed in all directions by a dense network of railways and highways, the main ones of which reach the western border of Ukraine. Lviv International Airport connects the

\footnotetext{
${ }^{4}$ Регіони України. 2018: стат. зб. Ч. 1. / За ред. І.С. Вернера. Київ, 2019. C. $13-19,28 \mathrm{c}$.
} 
region with many countries around the world. The total length of railway tracks is $2887 \mathrm{~km}$, of which $1023 \mathrm{~km}$ are electrified.

Recreational and tourist infrastructure of the Carpathian region provides an opportunity to rehabilitate up to 8 million people annually.

The most popular resorts is Truskavets, which specializes in the treatment of kidney disease, urinary tract, as well as organic digestion and metabolism. More than 300,000 people are served here annually. The second most powerful and popular resort is Morshyn. In Morshyn treat diseases of the kidneys, bile ducts, gastrointestinal tract and metabolic disorders. Over 75,000 people are served at the resort every year. Resorts in Yaremche, Vorokhta and Kosiv specialize in climatotherapy. The main resorts of the Carpathian region are presented in table 1.

Sports and recreational activities have significant opportunities in the Carpathian region. This primarily applies to skiing, tourism, hunting, speleological subspecies. There are several ski areas in the region. The importance of these zones will grow, as the Carpathians are the only region of Ukraine that has all the opportunities for its development. The main areas of skiing are Slavska and Rozlutska in Lviv, Volovets, Rakhiv, Yasinyanska in Zakarpattia, Vorokhtyanska in Ivano-Frankivsk regions. Recreational activities include swimming, beach and walking. The main natural resources that ensure their functioning are picturesque landscapes, the presence of water areas suitable for swimming, favorable climatic conditions. The western region has the richest hunting grounds in Ukraine. Sport hunting is possible almost throughout the Carpathians.

Table 1

The main resorts of the Western region ${ }^{5}$

\begin{tabular}{|c|c|c|}
\hline Region/oblast & Resorts of national importance & $\begin{array}{c}\text { Resorts place of } \\
\text { importance }\end{array}$ \\
\hline Transcarpathian & Golubyne, Polyana, Sinyak, Soim & Shayan \\
\hline Ivano-Frankivsk & Cherche, Yaremche & $\begin{array}{c}\text { Brusnytsia, Vorokhta, } \\
\text { Kvasy, Kosiv, Kremenets }\end{array}$ \\
\hline Lviv & $\begin{array}{c}\text { Lyubyn Velyky, Nemyriv, } \\
\text { Morshyn Skhidnytsia, Truskavets }\end{array}$ & Shklo \\
\hline Chernivtsi & & Myhove \\
\hline Ternopil & & Konopkivka, Husiatyn \\
\hline
\end{tabular}

${ }^{5}$ Курортні ресурси України. Київ: ЗАТ «Укпрофздоровниця», «ТАМЕД», 1999. 344 c. 
The average density of hunting species is $2-5$ times higher than the corresponding indicators of neighboring areas. With the creation of appropriate conditions, these territories can become popular internationally. In the Chernivtsi region, a number of large karst caves are known, among them one of the largest in the world "Cinderella" near the village Podvirne. The Carpathian rivers (Cheremosh, Prut, Tisza, Latorytsia, Rika, Tereblya, Uzh, Stryy and Dniester) have favorable conditions for the organization of water sports, first of all rafting in kayaks and canoes. Some peaks of Chornohora (Spytsia, Rebra, southern slopes of Hoverla and Petros), separate rocks in Ivano-Frankivsk, Zakarpattia regions, Marmaros crystal massif in Zakarpattia are suitable for mountaineering. These areas can be used for training athletes. The ridges of Chornohora and Svydivets have the greatest opportunities for organizing sports tourism.

Among the oblasts of the Western region, the number of rehabilitated in almost all sanatoriums and health facilities increased (except for Ternopil and Chernivtsi oblasts) until 2008 and decreased in the period of 2009-2010.

In the Western region, there is a network of children's health facilities, which are located throughout the region. The existing recreational and tourist potential of the Western region of Ukraine is represented by 3776 children's institutions. Their share in Ukraine in the number of children's institutions increased by $15,8 \%$ (from $6 \%$ to $21,8 \%$ ) and the number of places increased by $2,3 \%$ (from $10 \%$ to $12,3 \%)^{6}$.

The share of the regions in the Western region in Ukraine for the period 2000-2018 has not changed significantly. Ivano-Frankivsk region remains the leader in the number of camps, Lviv and Volyn regions are in second and third places, respectively, Chernivtsi region remains an outsider.

The increase in the number of children's institutions from 454 in 2000 to 3776 in 2010 and their capacity from 22,7 thousand places in 2000 to 24,2 thousand places in 2010 led to an increase in the number of healthy children who rested in these institutions. At the same time, there was a slight decrease in seats by an average of 12,3\% in 2009-2010.

Accordingly, the number of rehabilitated children who rested in children's health and recreation camps in the Western region increased by $44,4 \%$ - from 89,3 thousand people in 2010, to 409.2 thousand people in 2018. At the same time, the maximum value of this indicator was 508,7 thousand people in 2005, the minimum - 395,9 thousand people in 2009.

\footnotetext{
${ }^{6}$ Регіони України. 2018: стат. зб. Ч. 1. / За ред. І.С. Вернера. Київ, 2019. 323 с.
} 
Another, no less promising, area of health and recreation activities in the Western region is the development of tourism and active recreation.

The indicators of hotel development indirectly show the potential for tourism development. In terms of the number of hotels and other places for short-term accommodation, the championship in the Western region belongs to the Lviv region.

Typical indicators in the study of the infrastructure of the Western region are the official data on the activities of agro-villages or farmsteads. These data are given in table 2 .

All subject's of within rural green tourism operate in the form of individuals - entrepreneurs. In 2017, the situation regarding entrepreneurship in the field of rural green tourism changed somewhat, as shown in the summary tables. Ivano-Frankivsk, Lviv and Chernivtsi oblasts are the leaders among the oblasts of the Western region in terms of the number of tourists who have used the services of rural green tourism.

Table 2

Rural green tourism in the Western region of Ukraine in $2015-2017^{7}$

\begin{tabular}{|c|c|c|c|c|c|c|c|c|c|}
\hline \multirow{2}{*}{ Region / oblast } & \multicolumn{3}{|c|}{$\begin{array}{c}\text { Number of estates, } \\
\text { units }\end{array}$} & \multicolumn{3}{c|}{$\begin{array}{c}\text { Average capacity of } \\
\text { estates, places }\end{array}$} & \multicolumn{3}{c|}{$\begin{array}{c}\text { Number of } \\
\text { accommodated persons }\end{array}$} \\
\cline { 2 - 11 } & $\mathbf{2 0 1 5}$ & $\mathbf{2 0 1 6}$ & $\mathbf{2 0 1 7}$ & $\mathbf{2 0 1 5}$ & $\mathbf{2 0 1 6}$ & $\mathbf{2 0 1 7}$ & $\mathbf{2 0 1 5}$ & $\mathbf{2 0 1 6}$ & $\mathbf{2 0 1 7}$ \\
\hline Volyn & 2 & 2 & 2 & 15 & 15 & 15 & 2751 & 3067 & 3050 \\
\hline Transcarpathian & 8 & 7 & 8 & 19,1 & 20,6 & 9,5 & 1628 & 1356 & 488 \\
\hline $\begin{array}{c}\text { Ivano- } \\
\text { Frankivsk }\end{array}$ & 184 & 163 & 306 & 10,6 & 12,7 & 12,8 & 22935 & 16903 & 55096 \\
\hline Lviv & 36 & 23 & 14 & 13,5 & 13,9 & 19,5 & 8316 & 5227 & 2797 \\
\hline Rivne & - & - & - & - & - & - & - & - & - \\
\hline Ternopil & 4 & 3 & 6 & 18,3 & 21,3 & 26,5 & 1755 & 1804 & 4088 \\
\hline Khmelnytskyi & 6 & 5 & 6 & 20,8 & 23,8 & 23,5 & 4302 & 2728 & 397 \\
\hline Chernivtsi & 13 & 15 & 16 & 21,9 & 16,8 & 16,8 & 4720 & 5207 & 6974 \\
\hline Western & 256 & 218 & 358 & 14,9 & 14,1 & 15,4 & 46407 & 36292 & 72890 \\
\hline Ukraine & $\mathbf{2 8 5}$ & $\mathbf{2 3 3}$ & $\mathbf{3 7 7}$ & $\mathbf{1 2 , 6}$ & $\mathbf{1 3 , 5}$ & $\mathbf{1 3 , 5}$ & $\mathbf{4 9 9 4 8}$ & $\mathbf{3 9 3 1 1}$ & $\mathbf{8 2 5 7 0}$ \\
\hline
\end{tabular}

Thus, after the number of estates the Western region in 2015 presented $88,8 \%$ to the index in Ukraine accordingly in $2017-95,0$. The middle capacity of estates on this territory makes 14,9 units that are higher from middle Ukrainian on a 2,3 unit. Amount of persons that were in establishments presented $88,3 \%$ on the whole in Ukraine. It proves the high concentration of infrastructure in this region of country.

7 Колективні засоби розміщення в Україні у 2017: стат. зб. / Державна служба статистики України. Київ, 2018. 260 с. 
Mountain skiing resorts of the Western region of Ukraine. Mountains are located on territory of four areas of Ukraine: Lviv, Zakarpattia, Ivano-Frankivsk and Chernivtsi, a perspective district is the Ternopil area. Mountain peaks are snow-capped about 5 months for a year. Practically in any region there are places for rolling on skis are ski bases, sanatoriums are usually located in places suitable for rolling on skis and snowboards.

With every year the amount of skiing centers increases in the Western region of Ukraine, and quality of existing gets better. The variety of trails allows people with different levels of training to ride, and some resorts have specially designated descents for children. Bases are equipped with instructors and rescuers. However, in order to develop ski tourism, it is necessary to stimulate the development of tourist infrastructure facilities designed for the so-called trained consumer (middle class hotels and boarding houses, motels, tourist bases near major ski resorts, emergency medical care points, and ski equipment rental points). Lviv region has some of the best ski resorts in Ukraine (Tysovets $-750 \mathrm{~m}$ above sea level, $136 \mathrm{~km}$ from Lviv.), (Oryavchyk - $900 \mathrm{~m}$ above sea level, $133 \mathrm{~km}$ from Lviv), (Rozluch - $570 \mathrm{~m}$ above sea level, $121 \mathrm{~km}$ from Lviv), (Slavske $590 \mathrm{~m}$ above sea level, $138 \mathrm{~km}$ from Lviv).

Ivano-Frankivsk region is located in the Carpathians occupies a third part of them and due to the diversity of mountainous terrain is one of the most picturesque in Ukraine. The most popular mountains ski areas are Yaremche, Vorokhta, Bukovel, Yablunytsia, Verkhovyna, Kosiv, Sheshory. Bukovel is a modern ski resort of European level.

Chernivtsi region is actively developing mountain skiing tourism; the following ski resorts are popular: Myhovo, Nimchych, Horbovo and Sonyachna Dolyna.

Transcarpathian region, the largest mountains ski centers are: Dragobrat, Shayany, Izky, Krasiya and others.

Mountain skiing tourism in Ternopil region is not very developed. The industry is dependent on weather conditions; the places include Kremenets, Ternopil and the village Pidhorodne suburban area are the only currently existing cells.

Thus, the Western region is unique for tourism development. This is due to significant tourist resources (natural, historical, cultural, and infrastructural). Important logistics interchanges pass through the region. An important ethno-cultural heritage has been preserved in the area and there is relatively favorable environmental situation. Socio-economic features of the region, in particular the low level of industrialization of 
the territory, which can contribute to the expansion of tourism infrastructure. Extensive educational program to expand tourism potential.

\section{Analysis of main indicators of subjects of tourism activity of the Western region}

Subjects of Tourism Activity. Let us consider their features and identify patterns of tourism activities using different methods. The forecasting of tendencies of basic indicators of activity change is carried out and we substantiate priority directions of development of tourist sphere in border areas of the Western region of Ukraine

Because tourism is one of the most popular types of recreation in the world it is necessary to study in more detail the peculiarities of the development of this area and its relationship with social problems in the regions of Western Ukraine, which are close to the European Union. This involves conducting a statistical analysis of indicators that characterize the results of economic activity in the field of tourism in order to assess economic processes, to identify the main reasons that affect its development on the example of individual region

At the same time, today the tourism sector in the border areas of Western Ukraine needs more detailed study; they are quite attractive for the development of this type of activity due to the strengthening of European integration and prospects for expanding cooperation with the European Union.

Diagnosis of the main statistical indicators of activity of subjects of tourism industry, providing services (units) for 1999-2018 is shown in the table 3 and fic. 1 .

The beginning of the formation of tourism enterprises was in 1992, it was during this period that was formed a serious organizational and legal basis. This period was associated with an increase in the number of small enterprises, which took place after the so-called syndrome of their predecessors - mass co-operatives. Often these business entities were one-day registered, but did not report. 
Table 3

The dynamics of the number of subjects of tourism activity providing services (units) over 1999-2018 ${ }^{8}$. (calculated by the authors)

\begin{tabular}{|c|c|c|c|}
\hline Years & Ukraine & Western & $\begin{array}{c}\text { \%, of the number total of } \\
\text { subjects of tourism activity }\end{array}$ \\
\hline 1999 & 1776 & 335 & 18,9 \\
\hline 2000 & 2448 & 465 & 18,9 \\
\hline 2005 & 2145 & 408 & 19,0 \\
\hline 2010 & 4703 & 801 & 17,0 \\
\hline 2011 & 4773 & 812 & 17,0 \\
\hline 2012 & 5346 & 871 & 16,3 \\
\hline 2013 & 5711 & 890 & 15,6 \\
\hline 2014 & 3886 & 674 & 17,3 \\
\hline 2015 & 3182 & 606 & 19,0 \\
\hline 2016 & 3506 & 698 & 19,9 \\
\hline 2017 & 3469 & 776 & 22,4 \\
\hline 2018 & 4293 & 957 & 22,3 \\
\hline
\end{tabular}

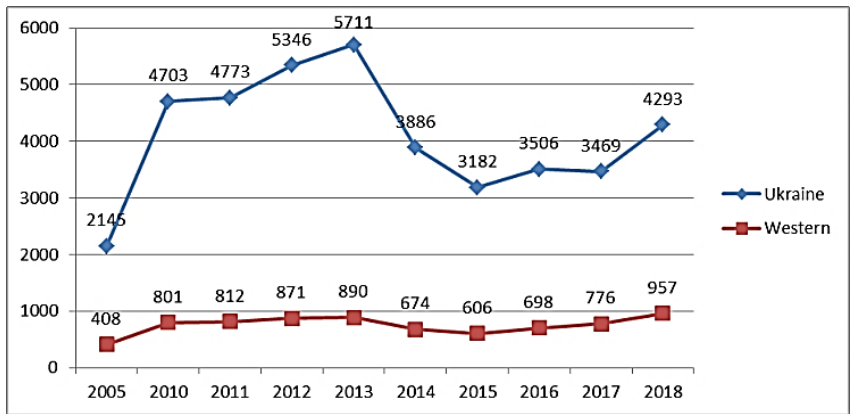

Fig. 1. The dynamics of the number of subjects of tourism activity providing services (units) over 2005-2018 ${ }^{9}$. (made by the author)

Nineties of the twentieth century were associated with the process of establishing a business tourism environment. So in 1993 the income tax was abolished and the profit tax came into force. In 1994 profits in the tourism sector were optimized. The 1996 crisis struck the sustainability of the tourism business as well as the subsequent 1998-1999.

Adopted in 1995, the Law of Ukraine "On Tourism", set the legal framework for the functioning of travel companies. From 1996 to 1999,

\footnotetext{
${ }^{8}$ Регіони України. 2018: стат. зб. Ч. 1. / За ред. І.Є. Вернера. Київ, 2019. 323 с.

${ }^{9}$ Там само..
} 
more than 800 enterprises appeared in the country. Since 2000 there has been a cease of the decline in tourism activity, which characterized the previous years.

Since 2006, the number of tourist enterprises has grown again, reaching a record number, but the next economic crisis occurred in 2008. However, this crisis did not significantly influence the state of the tourism business, as a certain stratum of tourists has already been formed.

In 2011 there were some amendments made to the Law "On Licensing Types of Economic Activities", according to which 52 types of economic activities, including travel agents, were withdrawn from the licensing.

The tendency to increase the number of subjects of tourism activity was noticeable until 2014, but the annexation of the Crimea and the seizure of the Donbas significantly reduced their number. Accordingly, their number reduced from 5711 in 2013 to 3885 in 2014, and military actions and inflation led to 3182 and 3506, respectively, in 2016.

As it can be seen from Table 1 in the Western region, the same trends can be clearly traced as in Ukraine generally, with the differences in 20132018, as there were no sharp reasons. Considering the structure of tourist flows in the regions of Western Ukraine during 2000-2010, it can be said that the share of inland tourists prevailed by $50 \%$ and its greatest amount was in 2007 at the level of $86,27 \%$, and the highest share of foreign tourists - in $2004-14,68 \%$. The solution of this problem should be carried out under constant control of state authorities and local self-government.

As it can be seen from tables 1, 2 and respectively Fig. 1. covering the Western region, the same trends as in Ukraine are clearly observed, only with differences in 2013-2016, as there were no sharp reasons.

The development and peculiarities of the activity of the tourist sphere of Western Ukraine are best reflected in the analysis of the total volume of tourists who were served by the subjects of tourist activity. Entities of tourist activity in the Western regions of Ukraine in 2010 served 375,369 people; the largest share belonged to domestic tourists $50.95 \%$, which is $40.7 \%$, or 160,295 people, more than cooperation in this area with foreign tourists and by $10,14 \%$, is by 38071 people - for tourists-citizens of Ukraine who went abroad. Drawing a parallel between these figures for 2010 and 2000, we can say that during this period the number of tourists decreased by 35,705 people, or $8.69 \%$. This was due to a decrease during the analyzed period in the number of domestic and foreign tourists, respectively by 36,965 people, or $16,2 \%$ and 8,338 people, or $21,2 \%$.

Considering the structure of tourist flows in the border regions of Western Ukraine during 2000-2010, we can say that the share of domestic 
tourists exceeded $50 \%$ and its highest value was in 2007 at $86.27 \%$, and the highest value of the share of foreign tourists - in $2004-14,68 \%$.

This shows that even though the western part of the country is a tourist-attractive territory due to the large number of historical monuments (Old Town (Lviv), Lubart Castle (Lutsk), etc.), natural features (Carpathians, Shatsky Lakes) and has common borders with European countries; all of these are popular among foreign tourists.

The solution to this problem should be carried out under the constant control of public authorities and local governments.

The number of subjects of tourism activity from 2010 to 2018 in the Western region increased from 801 to 957 units. As a percentage, it is 16,94 and $22,55 \%$, respectively, and the lowest share was in 2013 $15,6 \%$. This is due exclusively to the political and economic processes taking place in Ukraine. The reorientation of the market of tourist services to the west of the country is due to the loss of Crimea and part of the Azov coast. If, in general, there is a decrease in the number of subjects of tourism activity in the study area, their optimal number is maintained. The leaders in the number of tourism entities in 2018 are Lviv, Ivano-Frankivsk, Zakarpattia, Rivne regions. Outsiders are respectively Volyn, Ternopil, Chernivtsi regions. In fact, the Carpathian region has the largest number of tourist establishments. Popular destinations are the resort of Bukovel and sanatoriums of Transcarpathia.

Let's consider distribution of subjects of tourism activity in the context of the border regions of Western Ukraine (Table 4), (Fig. 2).

Lviv, Transcarpathian, Chernivtsi and Ivano-Frankivsk regions show the highest level of implementation of this service in 2012.

In 2017, in the Western region of Ukraine, there were 779 enterprises operating in the central part of the region; in the semi-peripheral part 349 legal entities and 430 individual entrepreneurs. The peripheral subsystem was formed by citizens who were engaged in commercial activities, but were not registered as small entrepreneurs. Their activity in the informal sector of the economy does not allow to access them. The statistical collections that were published during the previous years gave the count of the number of subjects that were registered and those who reported. This made it possible in a certain way to set the level of shadowing of this sector of the economy. However, nowadays to establish objectivity in the research the following numbers are used - the percentage of shadow economy in 2018 is claimed to be $40 \%$ and the level of criminalization $-5 \%$. so, we will not apply these indicators yet. 
Table 4

Number of subjects of tourism activity* Western region of Ukraine in $2010-2018$ (units) ${ }^{10}$. (calculated by the authors)

\begin{tabular}{|c|c|c|c|c|c|c|c|c|}
\hline \multirow[b]{2}{*}{ Region / oblast } & \multicolumn{4}{|c|}{$\begin{array}{c}2010 \\
\text { Including }\end{array}$} & \multicolumn{4}{|c|}{$\begin{array}{c}2018 \\
\text { Including }\end{array}$} \\
\hline & $\stackrel{\pi}{\stackrel{5}{\varrho}}$ & 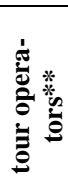 & 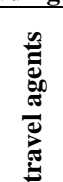 & 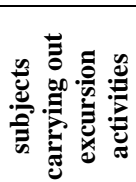 & है & 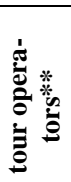 & 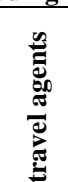 & 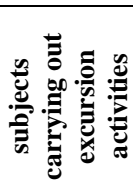 \\
\hline Volyn & 75 & 14 & 59 & 2 & 74 & 3 & 63 & 8 \\
\hline Transcarpathian & 147 & 16 & 118 & 13 & 91 & 14 & 75 & 2 \\
\hline Ivano-Frankivsk & 114 & 19 & 88 & 7 & 128 & 10 & 108 & 10 \\
\hline Lviv & 228 & 58 & 115 & 55 & 342 & 58 & 233 & 51 \\
\hline Rivne & 49 & 8 & 40 & 1 & 93 & 1 & 87 & 5 \\
\hline Ternopil & 71 & 11 & 55 & 5 & 63 & 7 & 51 & 5 \\
\hline Khmelnytskyi & 118 & 29 & 97 & 2 & 89 & 1 & 78 & 10 \\
\hline Chernivtsi & 118 & 29 & 87 & 2 & 77 & 9 & 67 & 1 \\
\hline Western & 801 & 154 & 562 & 85 & 957 & 103 & 762 & 92 \\
\hline Ukraine & 4793 & 877 & 3512 & 404 & 4293 & 529 & 3665 & 199 \\
\hline
\end{tabular}

${ }^{*}$ Here, the total includes legal entities and individuals - entrepreneurs.

*** Legal entities

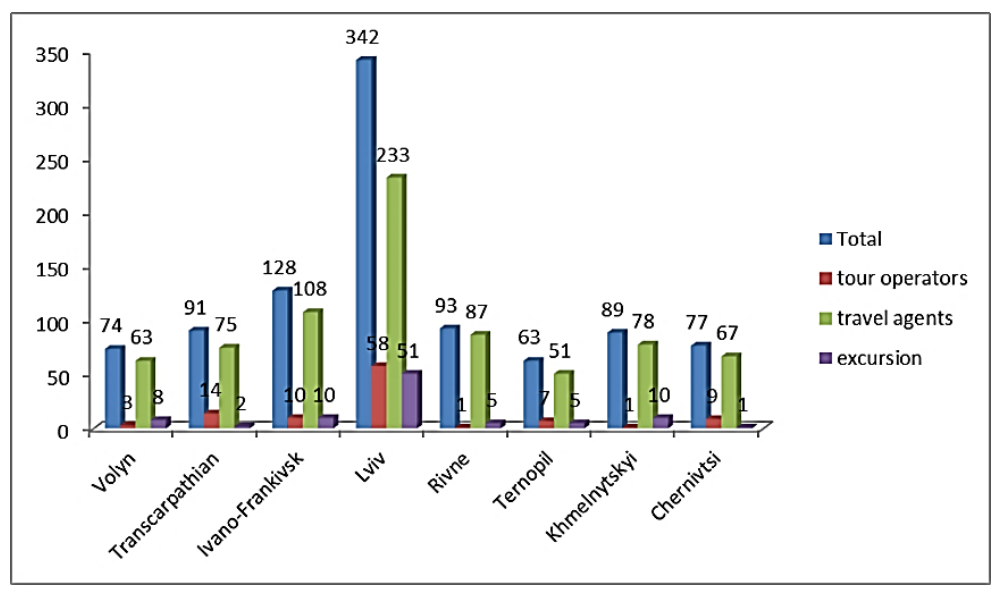

Fig. 2. Number of subjects of tourism activity Western region of Ukraine in 2018 (units) $)^{11}$. (made by author)

\footnotetext{
${ }^{10}$ Регіони України. 2018: стат. зб. Ч. 1. / За ред. І.Є. Вернера. Київ, 2019. 323 с.

11 Там само.
} 
Hence, the hypertrophied development of the semi-peripheral component of functioning in the total number is very high and it is the characteristic feature of tourism activity subjects in the Western region, as well as in Ukraine in general. Consequently, it can be stated that the activities of this sector of the economy are not a sign of civilized market relations.

During 2012-2018, the processes to increase the importance of tourists were carried out on the territory of Western Ukraine, to all areas except from the Transcarpathian region. Over the years the reduction of the services for trips organization was caused by the unstable financial situation in the country.

The number of tourists served by the subjects of tourist activity in the Western Ukraine region is shown in the table 5 and fig. 3.

Table 5

Number of tourists served by the subjects of tourist activity in the Western region of Ukraine* in 2010-2018 (persons) $^{12}$. (calculated by the author)

\begin{tabular}{|c|c|c|c|c|c|c|}
\hline \multirow{2}{*}{ Region / oblast } & \multicolumn{3}{|c|}{$\mathbf{2 0 1 0}$} & \multicolumn{3}{c|}{$\mathbf{2 0 1 8}$} \\
\cline { 2 - 7 } & \multicolumn{3}{|c|}{ Including } & \multicolumn{3}{c|}{ Including } \\
\cline { 2 - 7 } & Total & $\begin{array}{c}\text { tour } \\
\text { operators }\end{array}$ & $\begin{array}{c}\text { travel } \\
\text { agents }\end{array}$ & Total & $\begin{array}{c}\text { tour } \\
\text { operators }\end{array}$ & $\begin{array}{c}\text { travel } \\
\text { agents }\end{array}$ \\
\hline Volyn & 14657 & 4610 & 10047 & 21807 & 6191 & 15616 \\
\hline Transcarpathian & 217736 & 12565 & 9208 & 25348 & 4926 & 20422 \\
\hline Ivano-Frankivsk & 59327 & 48305 & 11022 & 55781 & 37153 & 18628 \\
\hline Lviv & 128709 & 59638 & 69071 & 182255 & 82677 & 99578 \\
\hline Rivne & 9490 & 2055 & 7435 & 22027 & 362 & 21665 \\
\hline Ternopil & 14164 & 9058 & 5106 & 13103 & 3131 & 9972 \\
\hline Khmelnytskyi & 24402 & 6056 & 18346 & 25738 & 378 & 25360 \\
\hline Chernivtsi & 36116 & 25471 & 10645 & 29562 & 4934 & 24628 \\
\hline Western & $\mathbf{5 0 4 6 0 1}$ & $\mathbf{1 6 7 7 5 8}$ & $\mathbf{1 4 0 8 8 0}$ & $\mathbf{3 7 5 6 2 1}$ & $\mathbf{1 3 9 7 5 2}$ & $\mathbf{2 3 5 8 6 9}$ \\
\hline Ukraine & $\mathbf{2 1 9 9 9 7 7}$ & $\mathbf{1 3 4 5 0 4 4}$ & $\mathbf{8 5 4 9 3 3}$ & $\mathbf{4 5 5 7 4 4 7}$ & $\mathbf{2 3 5 1 3 3 8}$ & $\mathbf{2 2 0 6 1 0 9}$ \\
\hline
\end{tabular}

*Here, the total includes legal entities and individuals - entrepreneurs.

Consequently, it is possible to draw conclusion, that on territory of areas of Western Ukraine during 2012-2018 there were processes related to the increase of size of tourists in all areas except for Transcarpathian. In the years of diminishing of volume of realization of services in organization of trips was caused an unstable financial situation in the state.

\footnotetext{
12 Регіони України. 2018: стат. зб. Ч. 1. / За ред. І.Є. Вернера. Київ, 2019. 323 с.
} 
Activity of subjects of tourist activity in the Western region has certain regional features. It can be investigated using statistical indexes for 10 thousand persons of population. In 2018 on the 10 thousand persons of population) in Ukraine there were $-2,32$ tourist enterprises. A leader among subjects of tourist activity in Ukraine is Kyiv - 13,97 (tour operators and travel agents on the 10 thousand persons of population), that exceeds total indexes the average in Ukraine. Part of business in tourist enterprises in a general amount present in Ukraine is 15,12 . The leader is the Lviv area -677 .

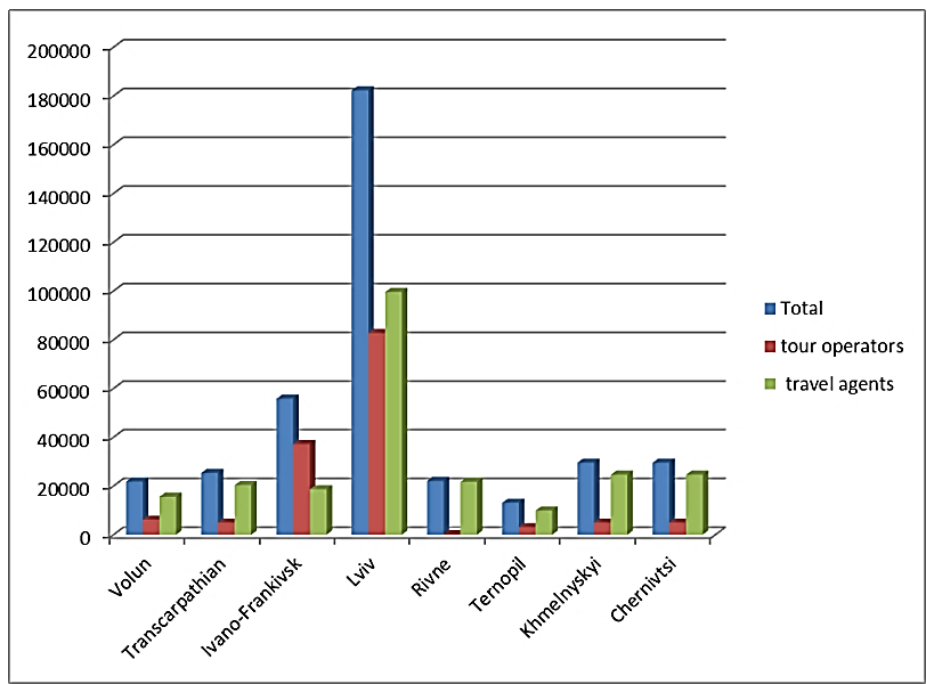

Fig. 3. Number of subjects of tourism activity Western region of Ukraine (persons) in 2018 (units) $)^{13}$. (made by author)

Tour operators and travel agents in the Western region of Ukraine in 2018 p. are shown in the table 6.

Though the conditions are unfavourable, the functioning of tourist business shows also a considerable break between the registered and operating enterprises.

Tourist industry in 2015, as well as in 2018 shows that the internal tourism takes up $75 \%$ tourists.

${ }^{13}$ Регіони України. 2018: стат. зб. Ч. 1. / За ред. І.С. Вернера. Київ, 2019. 323 с. 
Tour operators and travel agents in $2018^{14}$.

Table 6

(calculated by the author)

\begin{tabular}{|c|c|c|c|c|}
\hline Region / oblast & $\begin{array}{c}\text { Number of } \\
\text { tourists } \\
\text { enterprise, } \\
\text { units }\end{array}$ & $\begin{array}{c}\text { Number of } \\
\text { tourists } \\
\text { enterprise, on } \\
\text { the 10 thousand } \\
\text { persons of } \\
\text { population }\end{array}$ & $\begin{array}{c}\text { Number of } \\
\text { employees in } \\
\text { tourist } \\
\text { enterprises, } \\
\text { persons }\end{array}$ & $\begin{array}{c}\text { Share of } \\
\text { employees in } \\
\text { tourist } \\
\text { enterprises in the } \\
\text { total number of } \\
\text { employees, \% }\end{array}$ \\
\hline Volyn & 74 & 1,40 & 75 & 0,0002 \\
\hline Transcarpathian & 91 & 1,38 & 101 & 0,0002 \\
\hline Ivano-Frankivsk & 128 & 1,08 & 138 & 0,0003 \\
\hline Lviv & 342 & 0,74 & 677 & 0,0006 \\
\hline Rivne & 93 & 1,84 & 103 & 0,0002 \\
\hline Ternopil & 63 & 1,67 & 83 & 0,0002 \\
\hline Khmelnytskyi & 89 & 1,43 & 99 & 0,0002 \\
\hline Chernivtsi & 77 & 1,18 & 111 & 0,0003 \\
\hline Western & $\mathbf{9 5 7}$ & $\mathbf{2 , 3 2}$ & $\mathbf{1 4 9 0}$ & $\mathbf{0 , 0 0 0 2}$ \\
\hline Ukraine & $\mathbf{4 2 9 3}$ & $\mathbf{0 , 9 8}$ & $\mathbf{9 8 5 2}$ & $\mathbf{0 , 0 0 0 5}$ \\
\hline
\end{tabular}

\section{CONCLUSIONS}

The general conclusions on the problems of tourism in Ukraine are as follows:

1. Ukraine is a large country with a tradition in tourism that has been largely oriented to domestic, and previously, the Russian market, with a significant visitation of neighboring nationals in cross border areas.

2. Due to political processes, as well as to significant degree of misunderstanding and mismanagement, tourism has been neglected as an important economic sector over the last 15 years.

3. Although tourism is not considered as an important sector, economic assessments made in several studies show that it has more economic power than perceived;

4. Analysis of transport infrastructure problems:

- Overall interconnectivity of Ukrainian territory lags behind developed countries, especially in terms of road infrastructure making it one the major obstacles for higher tourism competitiveness;

- Ukraine has rather low indicators in terms of road lengths;

- Number of passengers is on the steady increasing trend, however density of infrastructure and passengers compared to area and population is still below international standard;

\footnotetext{
${ }^{14}$ Регіони України. 2018: стат. зб. Ч. 1. / За ред. І.Є. Вернера. Київ, 2019. 323 с.
} 
- Number of passengers in on the steady increasing trend, however density of infrastructure and passengers compared to area and population is still below international standards.

5. Travel and tourism competitiveness is improving, but is still behind countries from competitive set. Travel and tourism competitiveness Ukraine is placed 78th in 2019 edition, improving by ten places since the last edition in 2017.

Pandemic Covid-19 is a hard test into which the world ran from times of WWII. A crisis will have serious consequences in a global economy, here in obedience to the report of IMF, the forecast predicts fall of GDP from April, 2020 in Ukraine it will attain a mark 7,7\%. There are sufficiently different estimations in relation to subsequent renewal of global economy. Tourism is one of those sectors of world economy, that suffered most in connection with limits on a movement, and an especially difficult situation is in aviation industry. The scenarios published now forecast the declines of amount of international tourist arrival from $58 \%$ to $78 \%$ for a year, which depends on speed of distribution of virus.

In Ukraine today there is considerable lag in the rates of introduction of events in support a tourist sector that puts under a serious threat the competitiveness of industry at the global market during the forecast period of renewal during 2021.

\section{SUMMARY}

The study deals with the issues of the western region formation as one of the components of the socio-economic zoning and regional policy of the state. This research explores general state of the region's economy and the factors of unity of this territory as an object of sociogeographical research. There are discussed general problems of economy and specific administrative-territorial formations. The activity of the main subjects of tourist business, their creation, functioning, dynamic processes of social and economic indicators are superimposed on the framework of this territorial formation. There are also determined main types of tourism industry enterprises in Ukraine. The classification of main features of the tourism enterprises is paid special attention in the research. It is disclosed that the tourism sector structure is dominated by small tourism enterprises. Diagnostics of the basic statistical indicators of activity of tourism activity subjects that provided services in the Western Ukraine region is carried out and there are established its role 
and place in the market of tourist services of Ukraine. The main issues of the activities of tourism enterprises during the 1990's up to the present have been retrospectively viewed. The main indicators of the activities of tourism subjects are investigated using statistical methods.

\section{References:}

1. Долішній M.І., Шевчук Л.Т. Соціально-економічне районування України. Львів. 1997. 50 с.

2. Гнатюк М.Р. Закон України «Про туризм»: наук.-практ. коментар. Київ, 2006. 200 с.

3. Захарчин Г.М. Основи підприємництва. Київ, 2008. 437 с.

4. Євдокименко В.К. Регіональна політика розвитку туризму (Методологія формування, механізми реалізації ). Чернівці, 1996. $288 \mathrm{c.}$

5. Кифяк В.Ф. Організація туристичної діяльності в Україні. Чернівці, 2003. 300 c.

6. Колективні засоби розміщення в Україні у 2017: стат. зб. / Державна служба статистики України. Київ, 2018. 260 с.

7. Kowalczyk Andrzej. Geografia turuzmu. Warszawa, 2001. 288 c.

8. Кудла Н.С. Менеджмент туристичного підприємства. Київ, 2012. $343 \mathrm{c}$.

9. Курортні ресурси України. Київ: ЗАТ «Укпрофздоровниця», «ТАМЕД», 1999. 344 c.

10.Любіцева О.О. Ринок туристичних послуг (геопросторові аспекти). Київ, 2002. 436 с.

11. Мариняк Я. Створення й розвиток туристичних підприємств в Україні. Вісник Чернівецького національного університету імені Ю. Федьковича. 2008. С. 141-145.

12. Мариняк Я. Організаційні засади створення і діяльності туристичного підприємства: навч. посібник / за ред. В.Я. Брича. Тернопіль : ТНЕУ. С. 77-110.

13. Малий бізнес та підприємництво в ринкових умовах господарювання: монографія / за ред. Л.І. Воротіної. Київ : Європейський університет. 2001. 307 с.

14.Регіони України. 2018: стат. зб. Ч. 1. / За ред. І.Є. Вернера. Київ, 2019. 323 с.

15.Соціально-економічна географія України : навч. посібник / за ред. О.І. Шаблія. Львів : Світ, 1994. 608 с. 
16. Туристична діяльність у Тернопільській області в 2017 році. Статистичний бюлетень. Тернопіль. 2017. 38 с.

17.Туроперейтинг: навч. посібник /за ред. В.Я. Брича. Київ : Кондор, 2014. 276 c.

\section{Information about the authors: Maryniak Yaroslav Omelianovych,}

$\mathrm{PhD}$ in Geography, Associate Professor at the Department of Geography of Ukraine and Tourism Ternopil Volodymyr Hnatiuk National Pedagogical University 2, M. Kryvonosa str., Ternopil, 46027, Ukraine

Stetsko Nadiia Petrovna, $\mathrm{PhD}$ in Geography, Associate Professor at the Department of Geoecology and Methods of Environmental Discipline Ternopil Volodymyr Hnatiuk National Pedagogical University 2, M. Kryvonosa str., Ternopil, 46027, Ukraine 